\title{
Analisis Struktural Dan Makna Lukisan Dinding Gua Di Sulawesi Selatan
}

\section{Indah Asikin Nurani}

Keywords: migration, rock art, cave, prehistory, symbol, culture

\section{How to Cite:}

Nurani, I. A. (1999). Analisis Struktural Dan Makna Lukisan Dinding Gua Di Sulawesi Selatan. Berkala Arkeologi, 19(1), 53-65. https://doi.org/10.30883/jba.v19i1.792

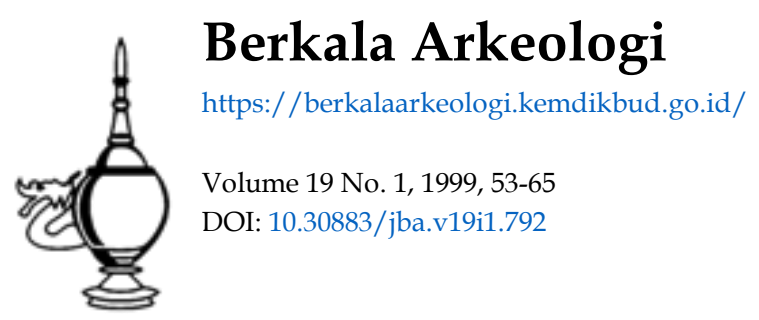

\section{c) (7) (2)}

This work is licensed under a Creative Commons Attribution-NonCommercial-ShareAlike 4.0 International License. 


\title{
ANALISIS STRUKTURAL DAN MAKNA LUKISAN DINDING GUA DI SULAWESI SELATAN
}

\author{
Indah Asikin Nurani \\ (Balai Arkeologi Yogyakarta)
}

\section{A. Pendahuluan}

Lukisan dinding gua atau yang lebih dikenal dengan istilah lukisan cadas merupakan salah satu unsur kebudayaan masyarakat prasejarah sebagai perwujudan hasil seni manusia masa itu. Sebagai salah satu karya seni, lukisan cadas tidak berbeda dengan karya seni lainnya yaitu untuk mengungkapkan perasaan batin manusia, penggambaran tentang apa yang dialami oleh seorang manusia, di samping mengandung nilai-nilai religius. Berdasarkan hal itu, maka hasil seni dalam penggambarannya kurang memperhatikan ketepatan anatomi serta proporsinya, unsur yang diutamakan lebih bersifat simbol-simbol. Hal itu karena karya seni lebih berfungsi untuk mengobyektifkan kehidupan batin, yang mampu dikontemplasi dan difahami maknanya. Dalam konteks demikian itu, fungsi seni dapat disejajarkan dengan fungsi bahasa, yaitu sebagai media komunikasi budaya yang simbolis sifatnya. Dengan demikian untuk memahami makna karya seni diperlukan pengetahuan budaya yang melatarinya (Sulistyanto, 1989).

Di Indonesia data lukisan cadas umumnya berkembang di bagian timur, seperti di Irian Jaya, Maluku, dan Sulawesi. Selama ini budaya tersebut belum pernah ditemukan di Jawa atau Sumatera. Berkaitan dengan sebaran budaya lukisan cadas yang hanya berkembang di Indonesia bagian timur, menarik untuk ditelusuri mengenai alur migrasi pembawa budaya tersebut. Selama ini penelitian mengenai hal tersebut masih menjadi perdebatan para ahli, beberapa yang sudah tampak jelas adalah adanya perbedaan unsur budaya antara Indonesia bagian timur dengan bagian barat. Sebagaimana disampaikan oleh A.S. Biskmore, seorang antropolog fisik menyimpulkan adanya dua ras yang menduduki Indonesia yaitu ras Melayu menduduki Indonesia bagian barat, sedangkan ras Papua menduduki Indonesia bagian timur. Sementara itu, C.M. Pleyte Wzn mengungkapkan adanya 2 arus migrasi dengan membawa unsur budayanya masing-masing. Unsur budaya alat sumpitan menyebar dan berkembang di Indonesia bagian barat, sedangkan alat busur berkembang di Indonesia bagian timur (Koentjaraningrat, 1987). Berkaitan dengan hal tersebut, tampak bahwa ada dua arus migrasi pembawa budaya yang berkembang di Indonesia bagian barat di satu pihak, dengan budaya yang berkembang di bagian timur di pihak lain. Hal tersebut tampak dengan persebaran lukisan cadas yang hanya berkembang di Indonesia bagian timur, sehingga timbul pertanyaan apakah pembawa budaya lukisan cadas ini berbeda dengan pembawa budaya yang berkembang di Indonesia bagian 
barat? Tulisan ini mencoba menjelaskan mengenai hal tersebut berdasarkan pada lukisan cadas yang ada di Sulawesi Selatan. Selain itu, berkaitan dengan produk budaya berupa lukisan cadas sebagai salah satu karya seni yang sarat simbol dalam menyampaikan pesan, maka perlu dikaji secara lebih mendalam tentang makna dan pesan yang sebenamya hendak disampaikan oleh pendukung budaya bersangkutan. Apakah ada keterkaitan antara makna lukisan dinding gua sebagai media penyampaian pesan dengan arus migrasi tersebut?

Berdasarkan pada permasalahan tersebut, untuk menelaah hal itu, dicoba dikaji melalui suatu pendekatan yang dianggap sesuai yaitu struktural. Pendekatan struktural merupakan suatu pendekatan untuk mengkaji makna yang tersembunyi dalam suatu hasil budaya terutama berupa simbol atau lambang. Hasil budaya sendiri dapat berupa benda material, tindakan kepercayaan, dan sikap yang berfungsi dalam kerangkakerangka yang diberi arti oleh lambang. Dengan demikian, kebudayaan merupakan produk yang dihasilkan oleh kemampuan manusia dalam menggunakan lambang, bagaimana kemampuan manusia dalam mengembangkan perangkat lambang akan menentukan tingkat pengetahuan dan gagasan manusia pendukung budaya tersebut (Santoso, 1981). Dalam hal ini lambang memiliki peranan penting sebagai alat komunikasi dalam menyampaikan pesan, begitu pula dengan lukisan dinding gua sebagai salah satu produk budaya yang merupakan upaya manusia dalam menyampaikan pesan melalui berbagai lambang dan simbol.

Dalam kaitannya dengan kajian strukturalisme tidak pernah lepas dari seorang tokoh antropolog terkenal Claude Levi-Strauss sebagai pencetusnya. Analisis struktural ala Levi-Strauss ini, dapat membantu mengungkapkan makna tersembunyi yang terdapat pada lambang, simbol, atau suatu cerita yang mengandung pesan tertentu dari pendukung budaya bersangkutan. Hal itu dikarenakan suatu dongeng atau mitos tidak hanya merupakan sebuah dongeng yang tanpa arti atau sekedar alat penghibur di waktu senggang saja. Sebuah dongeng seringkali juga merupakan suatu ungkapan simbolis dari konflik-konflik bathiniah yang ada dalam suatu masyarakat, serta menjadi sarana untuk mengelakkan, memindahkan dan mengatasi kontradiksikontradiksi yang tak terpecahkan, sehingga kontradiksi tersebut seolah-olah bisa dijelaskan, dipecahkan atau masuk akal (Ahimsa, 1994/1995). Berdasarkan pada kerangka fikir dalam analisis strukturalisme tersebut, maka untuk menelaah makna lukisan dinding gua, perlu pula diketahui cerita-cerita rakyat atau mitos yang beredar dan secara turun temurun dipercaya sebagai pencipta budaya tersebut. Hal itu penting dijabarkan berkaitan dengan asumsi, bahwa penceritaan kembali suatu mitologi dianggap mampu memberikan kekuatan dan keselamatan pada si pencerita. Cara penceritaan mitologi dapat melalui berbagai sarana sesuai dengan kemajuan budaya suatu masyarakat seperti melalui sandiwara, nyanyian, upacara, atau lukisan (Subagyo, 1981). 
Selain itu mitos juga merupakan fenomena kebahasaan, bahasa digunakan untuk menyampaikan pesan-pesan, demikian juga halnya dengan mitos. Di dalam mitos terkandung berbagai macam pesan, yang baru dapat difahami jika diketahui struktur dan makna berbagai elemen-elemen yang ada dalam mitos tersebut. Struktur mitos dapat dijelaskan dengan menunjukkan pada fungsinya, yakni sebagai media untuk mengembangkan suatu argumen logis dalam bentuk proposisi-proposisi. Melalui cara ini mitos dapat memecahkan atau "menjelaskan" kontradiksi dari kepercayaankepercayaan yang dianut oleh suatu masyarakat. Dalam pandangan Levi-Strauss kontradiksi yang ada sebagai upaya kognitif untuk memecahkan dan memindahkan konflik pada satu bidang --yang tidak dapat mereka pecahkan-- ke bidang yang lain, sehingga konflik atau kontradiksi tersebut tampak dapat diantarai (mediated), dan dengan demikian dapat dipecahkan (Ahimsa, 1994/1995).

\section{B. Lukisan Dinding Gua di Sulawesi Selatan}

Sehubungan dengan data lukisan dinding gua yang terdapat di Sulawesi Selatan hingga saat ini belum sepenuhnya terkumpul semuanya. Meskipun demikian, beberapa temuan baru menunjukkan tingkat kuantitatif yang lebih meningkat, sementara secara kualitatif atau jenis lukisan tetap sama. Berdasarkan hal tersebut, berikut akan diuraikan potensi lukisan dinding gua yang dianggap representatif yaitu di Kabupaten Maros dan Kabupaten Pangkep. Data diambil dari skripsi A. Ariobimo Nusantara (1989).

\section{Kabupaten Maros}

\section{Gua Burung 2}

Gua Burung 2 terdapat pada kaki sebuah perbukitan kapur yang memanjang dari utara ke selatan, terletak di sebelah timur Desa Tompokbalang, Kecamatan Bantimurung. Gua ini mempunyai 2 buah pintu masuk yang saling berhubungan, masing-masing menghadap ke barat dan timurlaut. Temuan lukisan pada gua ini meliputi cap-cap tangan berjari lengkap dengan latar belakang warna merah sejumlah 6 buah. Keletakan lukisan pada permukaan dinding dan atap gua yang cukup halus dibandingkan dengan permukaan yang lain.

\section{Gua PattaE}

Gua PattaE terdapat pada kaki perbukitan kapur leang-leang di Kalurahan Kalabbirang, Kecamatan Turikale. Gua ini merupakan sebuah ceruk yang cukup besar, mulut gua menghadap ke barat. Temuan lukisan yang terdapat pada gua ini meliputi cap tangan dan babirusa. Cap-cap tangan dilukiskan dengan latar belakang warna merah sejumlah 7 buah yang terletak pada dinding gua. Wujud tangan yang 
dilukiskan seluruhnya tangan kiri, berjari lengkap dan ramping. Keletakan lukisan pada dinding sebelah selatan, di atas sebuah ceruk, \pm 2.5 di atas permukaan gua. Sedangkan lukisan babi rusa digambarkan dengan tubuh menghadap keluar dalam posisi sedang melompat dan pada jantungnya tertancap mata panah. Di leher dan punggung terdapat lukisan 5 atau 6 berkas rambut yang kaku. Keletakan lukisan ini pada dinding ceruk yang terletak agak dalam, sempit, dan gelap.

\section{Kabupaten Pangkep}

\section{Gua Sakapao}

Gua Sakapao terletak di Kampung BelaE, Kalurahan Minasate'ne, Kecamatan Pangkajene. Keletakan gua ini pada sisi timur lereng gugusan pegunungan kapur di BelaE. Gua ini merupakan gua yang cukup besar dan luas, terdiri atas dinding-dinding sebelah utara, selatan, dan barat. Di sebelah barat terdapat sebuah lorong yang memanjang ke arah barat. Lorong ini mempunyai dinding utara dan selatan. Atap gua di bagian utara lebih rendah dari pada bagian selatan, yaitu sekitar 1.50 meter dari permukaan gua. Mulut gua menghadap ke timur. Sebagian besar lukisan terletak pada bagian atap yang rendah di sebelah utara dan dinding lorong gua sebelah utara. Selengkapnya lukisan yang ditemukan pada gua ini adalah sebagai berikut.

Pada atap gua ditemukan lukisan babirusa berwarna merah saling berdekatan, dua ekor dilukiskan sedang berlari, dan lukisan babirusa besar atau 2 ekor babirusa dalam posisi coitus (posisi kawin, kedua babirusa tersebut saling tumpang tindih). Di sekitar lukisan babirusa terdapat 8 cap tangan berjari lengkap, terdiri atas 5 cap tangan kanan, 2 cap tangan kiri, dan 1 cap tangan yang sudah tidak jelas lagi. Lima tangan dilukiskan hingga lengan, 3 buah dilukiskan sampai pergelangan tangan.

Pada atap bagian tengah ditemukan lukisan abstrak berupa enam garis berwarna merah (kemungkinan babirusa yang belum selesai). Di dekatnya terdapat 3 cap tangan berjari lengkap terdiri atas 2 cap tangan kanan, 1 cap tangan kiri, serta 1 cap ibu jari. Sedangkan pada dinding utara lorong, ditemukan 19 buah lukisan cap tangan berjari lengkap dengan latar warna merah.

\section{Gua Lompoa}

Gua Lompoa terletak di Desa BelaE, Kalurahan Minasate'ne, Kecamatan Pangkajene. Gua ini terletak sekitar $300 \mathrm{~m}$ di sebelah utara desa. Untuk mencapai gua harus menembus rawa-rawa sepanjang $50 \mathrm{~m}$ ke arah barat dari jalan desa. Di sepanjang rawa-rawa banyak ditumbuhi pohon rumbia. Gua ini terdiri atas 2 buah gua yang saling berdekatan dan dihubungkan oleh sebuah celah. Gua pertama terletak di sebelah barat dengan pintu masuk menghadap ke selatan. Pada dinding utara gua ini terdapat celah yang menghubungkan gua pertama dengan gua kedua. Mulut gua kedua 
menghadap ke arah barat dengan lebar sekitar $4 \mathrm{~m}$. Temuan lukisan lebih terkonsentrasi di dinding utara dan timur dari gua pertama. Secara keseluruhan temuan lukisan yang terdapat pada gua ini adalah sebagai berikut.

\section{- Bagian utara}

Lukisan manusia berwarna hitam dan hanya berupa garis luar, posisi berdiri, kedua tangan terbuka dan berada di samping kanan dan kiri badan, sedangkan kepala hanya berupa lingkaran dan belum menggambarkan wajah. Motif zigzag warna merah dan garis-garis yang saling berpotongan, mungkin merupakan lukisan ikan yang digambarkan secara tembus pandang. Selain itu, juga ditemukan lukisan cap tangan dalam keadaan utuh dengan jari lengkap.

\section{- Bagian timur}

Lukisan manusia dalam posisi berkelompok, motif garis zig zag warna hitam, lukisan manusia, lukisan yang menyerupai burung, lukisan manusia dengan kura-kura berwarna hitam, lukisan ikan, lukisan yang tumpang tindih (abstrak) warna merah, manusia yang siap melontarkan tombak warna hitam, lukisan perahu layar berwarna hitam, dan cap tangan kiri dan kanan

\section{Gua Garunggung}

Gua ini terletak di Kampung Kajuara, Desa Kalabbirang, Kecamatan Pangkeje. Mulut gua menghadap ke utara, di dalam gua masih berlangsung proses pembentukan stalaktit dan stalakmit serta perembesan air pada beberapa tempat. Untuk memudahkan pengenalan gua, maka denah gua dibagi menjadi 3 kelompok yaitu kelompok I terdiri dari dinding barat dan timur, kelompok II terdiri dari dinding barat bagian tengah, dinding timur bagian tengah, dan langit-langit gua, sedangkan kelompok III terdiri dari dinding barat bagian dalam, dinding selatan, dan dinding timur bagian dalam, dinding selatan, dan dinding timur bagian dalam. Temuan lukisan pada gua ini meliputi cap-cap tangan dan babirusa dengan latar belakang warna merah. Selengkapnya temuan lukisan pada gua ini adalah sebagai berikut.

Pada dinding timur kelompok I ditemukan lukisan 13 buah cap tangan kiri, terdiri atas 3 buah cap tangan kanan dewasa dan lukisan yang menyerupai cap tangan berbentuk ramping dan bercabang 3 . Selain itu, pada bagian ceruk ditemukan 8 buah cap tangan berjari lengkap terdiri atas 2 tangan kiri, 1 tangan kanan, dan 5 tidak jelas.

Lukisan pada kelompok III meliputi lukisan 10 buah cap tangan berjari lengkap yang terdiri atas 4 cap tangan kiri, 1 cap tangan kanan, dan 5 cap tangan yang tidak jelas. Selain itu ditemukan pula lukisan babirusa warna merah dan 5 cap tangan yang ramping 
Sedangkan pada dinding barat kelompok I dan II ditemukan lukisan 8 buah cap tangan dengan jari- jari lengkap : 3 cap tangan kiri, 2 cap tangan kanan, dan 3 cap tangan yang tidak jelas.

\section{Mitos dan Tafsir Makna Lukisan Dinding Gua.}

\section{Mitos dan cerita rakyat yang beredar berkenaan dengan lukisan dinding gua}

Sebagaimana telah disinggung pada awal tulisan ini, bahwa dalam analisis struktural hal terpenting untuk menelaah makna lukisan cadas adalah cerita rakyat atau mitos yang dipercaya secara turun temurun berkaitan dengan keberadaan lukisan tersebut. Untuk itu, beberapa mitos dan cerita rakyat yang berhasil dikumpulkan berkenaan dengan lukisan cadas dapat diuraikan sebagai berikut (Arifin, 1997).

\section{Mitos I.}

Diceritakan pada zaman dahulu ada seorang laki-laki dan dua orang perempuan yang datang dari arah matahari terbit. Sang laki-laki dan salah seorang perempuan, Omimin namanya, yang merupakan ibu seorang anak berkulit putih. Sedang perempuan lainnya berkulit hitam, mereka semuanya buta dan mencari jalannya dengan merabaraba dinding karang yang mereka lalui. Mereka berjalan ke arah matahari terbenam, semakin dekat ke sana mata mereka semakin terbuka dan akhirnya mereka dapat melihat. Pada suatu hari terjadilah perselisihan antara kedua perempuan ini, sehingga berpisahlah mereka. Yang berkulit hitam tinggal di tempat ini dan menjadi nenek moyang orang Papua, sementara Omimin meneruskan perjalanannya ke tempat matahari terbenam dan di sana menjadi leluhur orang-orang kulit putih.

\section{Mitos II}

Dahulu kala di Dukuh Jie, wilayah Tainda, hidup seorang laki-laki bernama Nau beserta keluarganya dan seorang wanita bernama Nakwainugi bersama anak gadisnya. Suatu hari Nakwainugi terluka oleh sebuah panah dan meninggal di Gua Pinjelu. Dari darahnya keluar kelelawar-kelelawar yang menghuni gua tersebut. Anak gadisnya yang kemudian menjadi istri Nau memperlihatkan kesedihannya dengan membuat gambar-gambar pada dinding gua tersebut.

\section{Mitos III}

Dahulu telah terjadi perang besar antara Sawai dan Hatue (sama dengan Wahai, yang dahulu tinggal di teluk Seleman). Seorang prajurit Sawai berhasil memenggal beberapa kepala orang Hatue dan darahnya membasahi tangannya. Untuk menghilangkan darah tersebut ia menepak sebuah batu karang, dan cap tangan yang sekarang terlihat merupakan tanda yang ditinggalkannya. 


\section{Tafsir makna motif yang pernah diteliti selama ini.}

Penelitian mengenai makna motif yang dilukiskan pada benda-benda budaya umumnya dan lukisan cadas khususnya, telah banyak dilakukan. Beberapa penafsiran berkaitan dengan penggambaran suatu motif telah diasumsikan antara lain sebagai perjalanan arwah nenek moyang, kematian, dan kontak magis. Berikut adalah tafsiran makna motif yang selama ini telah diteliti. Penafsiran makna ini penting diuraikan berkaitan dengan konsep dan kepercayaan yang melatari manusia pendukung budaya lukisan cadas, sehingga akan dapat diinterpretasikan lebih akurat yang didasarkan pada analisis struktural.

Lukisan cap-cap tangan dianggap sebagai jejak nenek moyang yang datang dari arah matahari terbit, dan dalam perjalanan ke arah matahari terbenam para leluhur menyelusuri gua-gua, sehingga jejaknya tertera pada dinding-dindingnya. Penggambaran motif geometris diyakini sebagai motif magis atau magic design (lambang totem) (Heekeren, 1958). Motif geometris tersebut antara lain motif matahari berbentuk lingkaran dengan garis-garis sinar, motif bulan yang diartikan sebagai lambang terang dan keagungan, dan bentuk geometris yang disusun secara tertentu melambangkan kosmos. Selain itu bentuk geometris dianggap juga sebagai perjalanan nenek moyang atau mitologi mereka.

Motif fauna seperti burung mempunyai makna sebagai lambang dunia atas. Pada Suku Dayak Ngaju di Kalimantan terdapat kepercayaan bahwa burung enggang (tinggang) dianggap sebagai perwujudan Dewa Mahatala atau dewa tertinggi (Hadiwiyono, 1985). Apabila burung dianggap sebagai lambang dunia atas, maka ikan sebagai simbol dunia bawah. Burung dan kadal dalam mitos-mitos kuna dianggap sebagai penjelmaan nenek moyang (Hoop, 1949).

Lukisan perahu merupakan salah satu unsur yang dominan dalam mitologi rakyat Indonesia. Orang Yamdena di Tanimbar (Maluku) beranggapan nitu atau arwah pergi ke dunia roh yang ada di seberang lautan atau di tempat matahari tenggelam dengan naik perahu. Bentuk perahu sebagai kendaraan arwah sering digambar sebagai burung, seperti pada masyarakat Dayak. Konsepsi perjalanan arwah dengan perahu tampaknya menjadi konsepsi umum bangsa Indonesia. Hal ini mungkin dilatarbelakangi proses migrasi penduduk dengan perahu. Bentuk perahu atau manusia kangkang dilukis sebagai penceriteraan kembali suatu mitologi. Tujuannya adalah penciptaan magi tiruan, agar roh si mati berhasil mencapai tempat dengan selamat. Demikian pula lukisan seekor babi yang melonjak terkena panah di jantungnya, merupakan kontak magis yang berkaitan dengan harapan usaha perburuan (Koentjaraningrat, 1977). Sementara itu, motif yang berkaitan dengan kematian meliputi bentuk geometris 
(lengkungan, lingkaran, spiral), perahu, manusia, dan binatang melata (Tanudirdjo, 1985).

\section{Analisis Struktural}

\section{Relasi antara mitos dengan lukisan sebagai wadah penceritaan}

Sebagaimana telah diuraikan di atas mengenai berbagai mitos dan tafsir mengenai makna lukisan dinding gua yang selama ini diteliti, berikut akan ditarik suatu relasi antara keduanya. Hal tersebut dilakukan sehubungan dengan pencarian makna dan pesan yang tersembunyi dalam lukisan dinding gua sebagai wadah penceritaan mitos yang merupakan sumber kekuatan dan keselamatan si pencerita.

Motif-motif lukisan gua yang ditemukan di Sulawesi Selatan dapat dikelompokkan dalam beberapa motif antara lain motif fauna, manusia, geometris, dan perahu. Motif fauna yang dilukisan antara lain babinusa, ikan, burung, dan kura-kura. Pada kenyataannya binatang-binatang tersebut bukan sekedar gambaran tentang jenis-jenis binatang yang hidup dan pernah dilihat oleh pelukis atau seniman pendukung budaya tersebut. Jenis-jenis binatang itu memiliki makna simbolis yang sarat pesan. Babirusa merupakan salah satu binatang buruan manusia penghuni gua yang sangat diharapkan dan menjadi sumber makanan saat itu. Dalam penggambarannya babirusa dapat diartikan sebagai binatang buruan saja seperti penggambaran 2 babirusa yang saling berdekatan atau babirusa dalam posisi berlari, namun dapat juga berarti religius seperti penggambaran babirusa yang tertancap mata panah pada jantungnya. Sedangkan penggambaran fauna lainnya seperti ikan, burung, dan kura-kura lebih bermakna religius. Sebagaimana telah diuraikan pada bagian sebelumnya binatang tersebut merupakan penggambaran tentang kehidupan religi manusia saat itu yang telah mengenal adanya alam kehidupan atas, tengah, dan bawah, serta mitologi nenek moyang mereka.

Lukisan manusia atau sebagian tubuh manusia menunjukkan adanya makna tersendiri pula. Hampir seluruh gua selalu ditemukan lukisan cap-cap tangan baik kiri maupun kanan, berjari lengkap maupun sebagian. Data tersebut menunjukkan kemungkinan bahwa cap-cap tangan memiliki makna sosial budaya, sebagai pertanda bahwa suatu gua dihuni. Hal itu berkenaan dengan upacara yang masih berlangsung di Soppeng, Sulawesi Selatan pada saat pendirian rumah panggung batu yaitu dengan pembubuhan telapak pada tiang rumah yang baru dibangun (Driwantoro, 1989). Upacara tersebut adalah dengan menempelkan telapak tangan kanan, atau kiri baik lengkap maupun tidak (tiga jari) yang telah dicelupkan ke dalam cairan yang merupakan bedak suci atau bedak dinging pada tiang utama dan tiang-tiang lainnya di tempat yang mudah dilihat. Maksud dari pembubuhan telapak tangan tersebut agar dapat menolak bahaya 
yang mungkin datang mengganggu ketenangan pemilik rumah. Dengan melakukan upacara ini diharapkan pemilik rumah selalu merasa senang hati, segar, dan dingin, artinya selalu terlepas dari kesirikan, rasa dengki, dan fitnah. Sedangkan penggambaran manusia sebagian besar memiliki makna sebagai perwujudan atau jelmaan nenek moyang dan mengandung maksud religi pemujaan.

Dalam kehidupan religi, motif-motif yang dilukiskan umumnya berbentuk geometris atau gejala alam seperti fauna, manusia, atau benda-benda lainnya. Untuk mengadakan hubungan sebaik-baiknya dengan roh nenek moyang, manusia senantiasa melakukan berbagai upacara pemujaan. Dengan upacara tersebut manusia mengharapkan agar roh nenek moyang memberikan bantuan kepada manusia. Diperkirakan dalam upacara religius tersebut disertai pula dengan pembuatan lukisan dinding gua sebagai penceritaan mitologi nenek moyang (Tanudirdjo, 1985). Dalam hal ini lukisan dinding gua digunakan sebagai media penceritaan mitologi yang memiliki peranan penting bagi si pencerita. Sebagaimana lukisan geometris yang dianggap sebagai lambang totem atau kisah perjalanan nenek moyang yang merupakan magi tiruan untuk menjamin roh berhasil kembali ke sumber totem.

\title{
2. Relasi atas tafsir mitos
}

Langkah awal dalam tafsir mitos ini adalah dengan cara memotong-motong kisah tersebut pada beberapa episode. Hal tersebut dapat dilakukan dengan mencari unitunit yang memiliki relasi antar elemen dalam cerita. Berikut akan dianalisis ketiga mitos berkenaan dengan lukisan dinding gua sebagaimana telah diuraikan di depan.

\begin{abstract}
Mitos I
Dalam mitos I ini episode penting yang dapat disusun meliputi 4 hal. Pertama adalah datang dari arah matahari terbit dan pergi ke arah matahari tenggelam. Episode pertama ini menunjukkan adanya suatu perjalan dari arah matahari terbit (timur) ke arah matahari tenggelam (barat). Hal ini dapat ditafsirkan adanya arus perpindahan atau migrasi suatu budaya dari timur ke barat. Perjalanan tersebut dilakukan oleh 2 kelompok manusia dengan ras yang berbeda yaitu berkulit putih dan berkulit hitam. Kedua kelompok tersebut memiliki budaya yang berbeda dan di antara keduanya tidak saling mengenal. Hal itu ditunjukkan pada episode kedua yaitu awal kepergiannya buta dan akhir perjalanannya dapat melihat. Episode kedua ini menunjukkan bahwa awal perjalanan itu kedua ras tidak melihat/buta (tidak mengenal) budaya lainnya, namun semakin ke arah barat kedua ras tersebut semakin dapat melihat atau mengenal budaya satu dengan lainnya. Berikutnya adalah episode ketiga yaitu awalnya damai dan akhimya berselisih dan berpisah. Episode ini menunjukkan setelah saling mengenal dan mampu melihat masing-masing budaya kedua ras atau kelompok ini,
\end{abstract}


mereka dapat hidup berdampingan dan damai dengan budaya masing-masing. Hingga suatu saat keldua ras atau kelompok ini berselisih atau berperang. Akibat perselisihan ini menyebabkan wanita berkulit putih meneruskan perjalanannya ke arah barat, sedangkan wanita berkulit hitam tetap tinggal (episode keempat). Episode keempat ini menyiratkan bahwa kelompok ras kulit putih melanjutkan perjalanannya untuk menyebarkan budayanya ke arah barat, sementara kelompok ras kulit hitam tetap tinggal dan mengembangkan budaya di bagian timur. Dalam episode keempat ini disebutkan wanita adalah simbol ibu sebagai penerus keturunan, sehingga dalam hal ini wanita dimaksudkan kedua kelompok terus berkembang dan meneruskan keturunannya dengan mewariskan budaya yang dibawanya.

Berdasarkan pada tafsir mitos I ini, apabila dikaitkan dengan asumsi adanya 2 arus migrasi yang ada di Indonesia, tampak jelas keterkaitannya. Kedua kelompok ras tersebut dapat ditafsirkan sebagai ras Melayu (kulit putih) dan ras Papua (kulit hitam). Kedua ras tersebut awalnya mengembangkan budayanya bersama-sama di Indonesia bagian timur (Sulawesi?), selanjutnya ras Melayu lebih mengembangkan dan menyebarkan budaya ke arah barat, sementara ras Papua tetap mengembangkan budayanya di bagian timur. Berkaitan dengan pengaruh budaya yang tercermin pada lukisan dinding gua mengenai kedua ras yang hidup berdampingan tersebut dapat ditunjukkan pada fenomena warna (merah dan hitam) pada lukisan dan motif-motif lukisan yang semakin beragam. Selain itu, motif terpenting yang menunjukkan adanya arus migrasi tersebut adalah lukisan perahu layar. Lukisan perahu selain mencerminkan kehidupan religius sebagai wahana dalam perjalanan arwah nenek moyang, juga menunjukkan sebagai alat transportasi.

Mitos II dan Mitos III

Dalam mitos kedua ini, terdapat 3 episode yang dapat dipisahkan yaitu episode pertama : terluka oleh sebuah panah dan meninggal di gua, episode kedua : darahnya keluar kelelawar-kelelawar penghuni gua tersebut dan episode ketiga memperlihatkan kesedihannya dengan membuat gambar-gambar pada dinding gua. Berdasarkan pembagian ketiga episode tersebut dapat ditafsirkan bahwa lukisan dinding gua dimaksudkan sebagai cerminan kehidupan religius yaitu kematian. Dari darahnya keluar kelelawar-kelelawar penghuni gua dapat ditafsirkan sebagai keturunan Nakwainugi yang mewarisi budaya lukisan dinding gua dan bertempat tinggal di gua. Selanjutnya episode ketiga dapat ditafsirkan bahwa dalam mengenang (memuja nenek moyang) maka dilakukan upacara dengan membuat gambar-gambar pada dinding gua. Sayang sekali, mitos ini tidak seluruhnya dapat diterima secara lengkap, sehingga tidak dapat ditafsirkan mengenai siapa Nakwainugi dan budaya yang dibawanya. 
Sedangkan pada mitos III dapat dibagi dalam 3 epișode yaitu episode pertama : terjadi perang besar, episode kedua : memenggal beberapa kepala, dan episode ketiga : darah membasahi tangannya. Berdasarkan pada ketiga episode tersebut dapat ditafsirkan adanya dua kelompok budaya yang saling berperang. Dalam peperangan tersebut sebagai tanda kemenganan adalah dengan memenggal kepala yang diwujudkan dalam lukisan-lukisan dinding gua. Hal tersebut dapat ditafsirkan bahwa lukisan dinding gua merupakan suatu tanda kemenangan dan keampuhan dari suatu kelompok dengan menggambarkan cap-cap tangan.

\section{E. Kesimpulan}

Berdasarkan uraian tersebut di atas, dapat disimpulkan hal-hal sebagai berikut.

- Lukisan dinding gua sebagai media penceritaan kembali mitos yang dianggap memiliki kekuatan dan keselamatan bagi si pencerita, merupakan suatu pesan yang sarat simbol dan lambang.

- Relasi antara mitos dan makna lukisan dinding gua menunjukkan penggambaran sosial budaya, ekonomi, dan religi manusia masa prasejarah. Kehidupan sosial budaya tercermin pada pelukisan eap-cap tangan, perahu, dan manusia berkelompok. Kehidupan ekonomi tercermin pada lukisan babirusa sebagai sumber makanan dan perahu sebagai alat transportasi. Sedangkan kehidupan religi yang telah dianut manusia saat itu tercermin pada pengenalan dunia atas, tengah, dan bawah yang digambarkan sebagai burung dan motif geometris (dunia atas), manusia dan babirusa (dunia tengah), dan ikan dan kura-kura (dunia bawah). Selain itu sebagai pemujaan terhadap arwah nenek moyang dilukiskan dalam motif perahu, binatang melata, dan manusia kangkang. Kehidupan religi lainnya tercermin pada lukisan geometris, perahu, binatang melata, dan manusia sebagai mitologi kematian.

Selain itu, dari aspek keletakan lukisan-lukisan menunjukkan adanya kekhususan tersendiri. Motif-motif yang mencerminkan kehidupan sosial, biasanya terletak pada daerah atau ruangan gua yang mudah dijangkau dan dilihat seperti lukisan cap-cap tangan dan babirusa yang terletak pada bagian ceruk atau dinding-dinding dekat mulut gua. Sedangkan motif-motif lukisan yang mencerminkan kehidupan religi seperti lukisan babirusa dengan mata panah tertancap di jantungnya, perahu arwah, dan motif geometris terletak pada ruangan gua yang sempit, dalam, dan gelap.

- Dalam mitos yang berkaitan dengan lukisan dapat diketahui adanya pesan yang tersirat mengenai alur perjalanan migrasi pembawa budaya yang sampai ke 
Indonesia. Arus migrasi dengan membawa budaya masing-masing sampai ke Indonesia berasal dari arah timur menuju barat. Pembawa budaya tersebut adalah ras Papua dan ras Melayu yang pada awalnya hidup berdampingan dengan budaya masing-masing, namun akhirnya kedua ras tersebut berselisih dan berpisah. Ras Papua tetap mengembangkan budayanya di Indonesia bagian timur, sementara ras Melayu mengembangkan budayanya ke bagian barat. Hal tersebut menyebabkan adanya perbedaan perkembangan budaya di Indonesia bagian timur dengan budaya yang berkembang di Indonesia bagian barat. 


\section{KEPUSTAKAAN}

Ahimsa-Putra, Heddy Shri, 1994/1995. Analisis Struktural dan Malena Mithos Orang Bajo. Laporan Penelitian. Yogyakarta : Fakultas Sastra Unuversitas Gadjah Mada.

Arifin, Karina, 1997. Penelitian Rock Art di Indonesia dari Deskripsi sampai Malena. Makalah disampaikan dalam Seminar Hasil Penelitian tanggal 24 November, Depok : Pusat Penelitian Kemasyarakatan dan Budaya Lembaga Penelitian Universitas Indonesia.

Driwantoro, Dubel, 1989. Gambar Telapak tangan di Soppeng, Suatu Upacara Religi : Kaitannya dengan Tradisi Budaya Prasejarah di Sulwesi Selatan (Etnoarkeologi). PIA V: hlm. 190-204.

Hoop, A.NJ.Th. A.Th. Van de, 1949. Ragam-ragam Perhiasan Indonesia. Ninklijke Bataviaasch Genootschap van Kunsten en Wetenscappen.

Koentjaraningrat, 1977. Beberapa Pokok Antropologi Sosial. Bandung Dian Rakyat.

Koentjaraningrat, 1987, Sejarah Teori Antropologi J. Jakarta: Universitas Indonesia Press.

Nusantara, A. Ariobimo, 1989. Kronologi Lukisan Dinding Gua di Kabupaten Maros dan Pangkep, Sulawesi Selatan. Tinjauan Berdasarkan Analisis Kontekstual. Skripsi Jurusan Arkeologi Fakultas Sastra Universitas Gadjah Mada.

Santoso, S. Budhi, 1981. Tradisi Lisan sebagai Sumber/nformasi Kebudayaan, Analisis Kebudayaan Tahun I No. 2, him. 63 --67.

Subagya, Rachmat, 1981. Agama Asli Indonesia. Jakarta Yayasan Cipta Loka Caraka Penerbit Sinar Harapan.

Soelistyanto, B. (1989). Proses Perkembangan Kesenian Dalam Perubahan Kebudayaan. Berkala Arkeologi, 10(2), 31-51. https://doi.org/10.30883/ jba.v10i2.542

Tanudirjo, D. A. (1985). Lukisan Dinding Goa Sebagai Salah Satu Unsur Upacara Kematian. Berkala Arkeologi, 6(1), 1-13. https://doi.org/10.30883/jba.v6i1.431 